\title{
REALIZING AN ASEAN ECONOMIC COMMUNITY: PROGRESS AND REMAINING CHALLENGES
}

Jayant Menon and Anna Cassandra Melendez

NO. 432

May 2015
ADB ECONOMICS WORKING PAPER SERIES 
ADB Economics Working Paper Series

\section{Realizing an ASEAN Economic Community: Progress and Remaining Challenges}

Jayant Menon and Anna Cassandra Melendez

No. 432 | May 2015
Jayant Menon (jmenon@adb.org) is Lead Economist from the Asian Development Bank (ADB) and Anna Cassandra Melendez (acmelendez.consultant@adb.org) is a consultant of $A D B$.

We are grateful for comments received from Chia Siow Yue and other participants of the RSISEconomic Growth Center Conference on ASEAN's Long-term Economic Potential and Vision on 20-21 November 2014 in Singapore. 
Asian Development Bank

6 ADB Avenue, Mandaluyong City

1550 Metro Manila, Philippines

www.adb.org

(C) 2015 by Asian Development Bank

May 2015

ISSN 2313-6537 (Print), 2313-6545 (e-ISSN)

Publication Stock No. WPS157302-2

The views expressed in this paper are those of the authors and do not necessarily reflect the views and policies of the Asian Development Bank (ADB) or its Board of Governors or the governments they represent.

ADB does not guarantee the accuracy of the data included in this publication and accepts no responsibility for any consequence of their use.

By making any designation of or reference to a particular territory or geographic area, or by using the term "country" in this document, $A D B$ does not intend to make any judgments as to the legal or other status of any territory or area.

Note: In this publication, "\$" refers to US dollars.

The ADB Economics Working Paper Series is a forum for stimulating discussion and eliciting feedback on ongoing and recently completed research and policy studies undertaken by the Asian Development Bank (ADB) staff, consultants, or resource persons. The series deals with key economic and development problems, particularly those facing the Asia and Pacific region; as well as conceptual, analytical, or methodological issues relating to project/program economic analysis, and statistical data and measurement. The series aims to enhance the knowledge on Asia's development and policy challenges; strengthen analytical rigor and quality of ADB's country partnership strategies, and its subregional and country operations; and improve the quality and availability of statistical data and development indicators for monitoring development effectiveness.

The ADB Economics Working Paper Series is a quick-disseminating, informal publication whose titles could subsequently be revised for publication as articles in professional journals or chapters in books. The series is maintained by the Economic Research and Regional Cooperation Department. 


\section{CONTENTS}

ABSTRACT IV

$\begin{array}{lll}\text { I. INTRODUCTION } & 1\end{array}$

II. MEASURING PROGRESS: THE ASEAN ECONOMIC COMMUNITY SCORECARD 1

III. REALIZING THE ASEAN ECONOMIC COMMUNITY: OBSTACLES, CHALLENGES, AND POSSIBLE SOLUTIONS

A. $\quad$ Pillar 1: Single Market and Production Base 3

B. Pillar 2: Highly Competitive Economic Region 9

C. Pillar 3: A Region of Equitable Economic Development 10

D. Pillar 4: Integration into the Global Economy 11

IV. BEYOND ASEAN ECONOMIC COMMUNITY 2015

V. CONCLUSION 16

$\begin{array}{ll}\text { REFERENCES } & 19\end{array}$ 


\begin{abstract}
Launched as a political bloc and security pact in the aftermath of the Viet Nam War, the Association of Southeast Asian Nations (ASEAN) has evolved to embrace an ambitious economic agenda. Its latest project is to establish the ASEAN Economic Community (AEC) by 31 December 2015. Fulfilling these commitments would promote predictability in ASEAN, as well as strengthen its credibility. But is ASEAN likely to meet this deadline? The blueprint for achieving the goal envisages the AEC standing on four pillars and meeting the deadline depends on progress on each of them. Each pillar presents a demanding set of challenges to be met before the AEC can be fully realized. We find that although ASEAN has come a long way toward realizing its goal, the challenges that remain suggest that the AEC will miss its approaching deadline. Accommodating AEC accords will not be easy when they require changes to domestic laws or even the national constitution. The flexibility that characterizes ASEAN cooperation, the celebrated "ASEAN way," may hand member states a convenient pretext for noncompliance. How to enforce the accords remains an issue. If the AEC is to be more than a display of political solidarity, ASEAN must find a way to give the commitments more teeth. The real test for the community, therefore, will lie in the years ahead.
\end{abstract}

Keywords: AEC 2015, ASEAN Economic Community, ASEAN economic integration, ASEAN trade and investment, economic integration, post-2015 agenda

JEL Classification: F13, F15, F20 


\section{INTRODUCTION}

Launched as a political bloc and security pact in the aftermath of the Viet Nam War, ASEAN has evolved to embrace an ambitious economic agenda. Its latest project is to establish the ASEAN Economic Community (AEC) by 31 December 2015. ASEAN leaders had originally intended to create the AEC by 2020, but in early 2007 they advanced the deadline to 2015.

At the $13^{\text {th }}$ ASEAN Summit held in Singapore on 20 November 2007, the ASEAN leaders adopted the ASEAN Economic Blueprint for an AEC. The Economic Blueprint defines four pillars of the AEC, contains 17 "core elements," and 176 priority actions to serve as a guide. It also contains agreed goals and specific commitments to be carried out within definite timelines, with a "Strategic Schedule" in the form of a matrix specifying "Priority Actions" to be undertaken over four 2-year periods from 2008 to 2015. Fulfilling these commitments would promote predictability in ASEAN as well as strengthen its credibility. But is ASEAN likely to meet this deadline?

\section{MEASURING PROGRESS: THE ASEAN ECONOMIC COMMUNITY SCORECARD}

Progress on AEC implementation is meant to be measured through an AEC Scorecard mechanism, established in 2008. The AEC Scorecard is a self-assessment tool that monitors the achievement of milestones indicated in the Economic Blueprint's Strategic Schedule. It also tracks specific actions that must be undertaken by ASEAN Member States, both individually and collectively, to establish the AEC (Das 2012).

The ASEAN Secretariat has published two AEC Scorecards, covering the first two phases of AEC implementation (2008-2009 and 2010-2011). Unfortunately, subsequent Scorecards have not been made available to the public. Progress on the AEC is still reported in various ASEAN Secretariat (ASEC) publications and staff reports, but this is no longer done in a systematic fashion as with the previous AEC Scorecard publications, which tracked implementation rates for each pillar and reported progress on the different elements of each pillar.

According to the ASEAN Annual Report 2013-2014, by end-2013, 81.7\% of the 229 AEC prioritized key deliverables targeted by 2013 have been implemented. Unfortunately, the report fails to provide a breakdown of implementation rates per pillar.

A somewhat more detailed ASEC presentation on AEC implementation provides an idea of where the bottlenecks lie. Of the AEC targets that were due by March 2013, implementation rates were highest in Pillar 1, followed by Pillars 2, 3, and 4, although no explanation for these rates was given in the presentation (see figure below). 


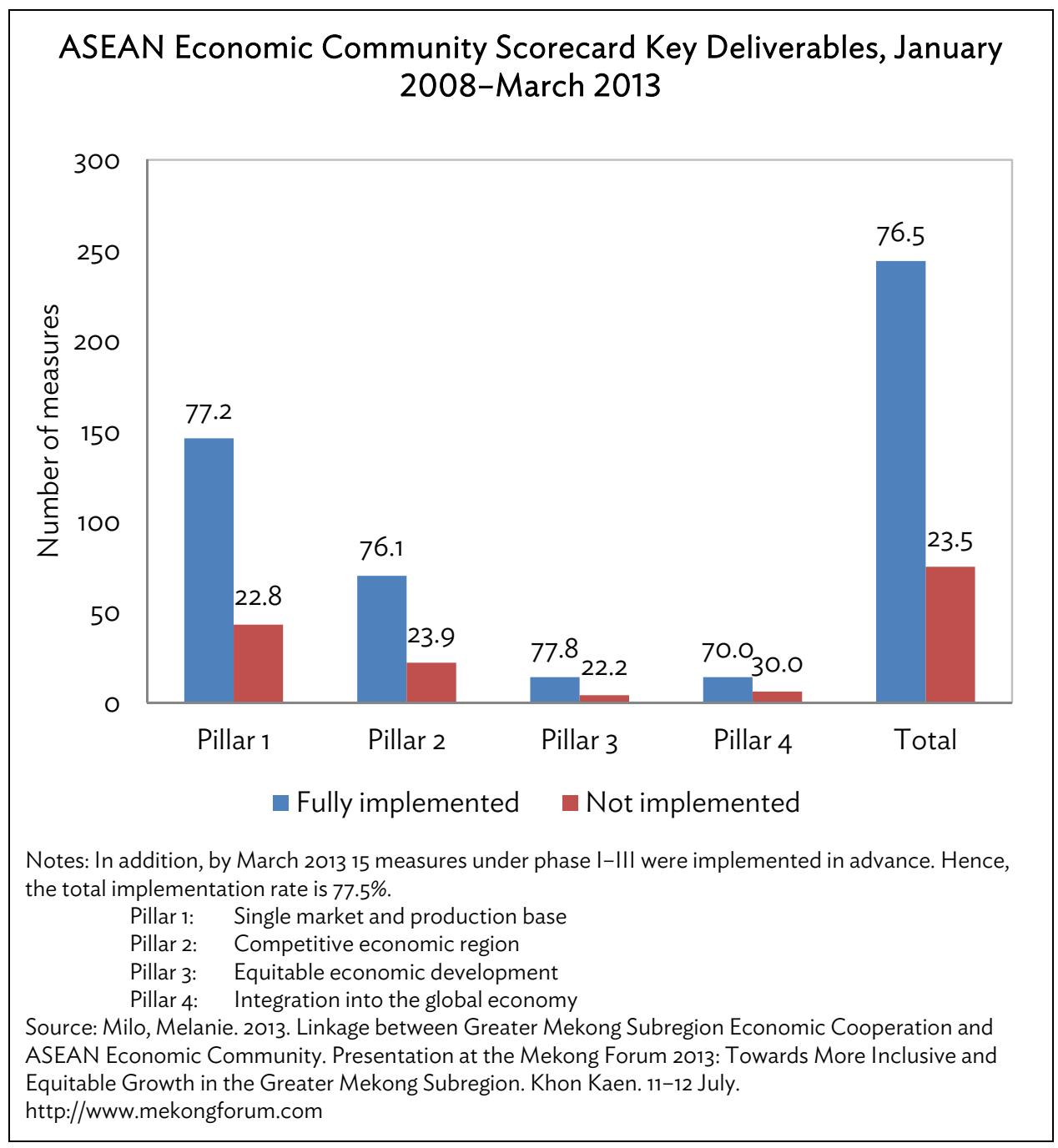

In any case, these Scorecard results need to be taken with a grain of salt, for several reasons. First, the AEC Scorecard is a compliance tool that relies on self-assessment. While ASEAN Member States may be willing to give a fair and balanced view of their progress, the need to meet the 2015 deadline could understandably lead countries to overestimate compliance and achievement. Second, the AEC Scorecard measures aggregate progress, thereby glossing over significant challenges to implementation within individual countries, with reporting essentially emanating from the AMS' capital cities. Very little is known about the extent to which other regions or provinces within the AMS are faring with respect to meeting AEC objectives.

Third, given the ASEAN's diversity-and sensitivities on different issues and sectorsmembers agreed that liberalization of goods, capital, and (skilled) labor flows would proceed at different speeds, according to each country's readiness. Thus, the "Strategic Schedule" remains saddled with loopholes and "flexibility" hedges, full of words and phrases like "minimal," "where appropriate and possible," "establish good practices," and "possibly" (Severino and Menon 2013). The Scorecard, however, fails to fully capture these differences.

Fourth, the AEC Scorecard does not try to analyze or explain the results. In the case of achievements, progress toward realizing the AEC involves significant amounts of double counting, 
whereby reforms undertaken under different initiatives and before the AEC proposal was launched are still being added to the tally. In the case of shortfalls or delays in implementation, the Scorecard falls short of examining the reasons for these delays and suggesting ways to improve implementation (Das 2012).

Perhaps the biggest shortcoming of the AEC Scorecard is that there is no mechanism for exerting peer pressure or enforcing sanctions when the AEC targets are missed. The country-based Scorecards are kept confidential, which effectively rules out peer pressure and makes it difficult for working committees or expert meetings to assess and address implementation bottlenecks (ADBI 2014).

Finally, one must bear in mind that the AEC Scorecard measures the implementation of milestones and priority actions identified in the Economic Blueprint; in other words, it measures the means, rather than the end of the AEC. Implementation of the Blueprint's priority actions may bring us toward the AEC, but even this may not mean the full realization of the AEC's lofty objectives.

Given Scorecard limitations and doubts surrounding its ability to provide an objective assessment of implementation, the question remains-how far has ASEAN gone in carrying out the more significant commitments under the AEC Economic Blueprint? And why has ASEAN or its members succeeded or failed in achieving them?

In the next section, we summarize progress and the remaining challenges that must be addressed under each of the AEC's four pillars. In the absence of more recent AEC Scorecards, our discussion will draw upon material from The ASEAN Economic Community: A Work in Progress, a joint publication of the ADB and the Institute of Southeast Asian Studies; the ASEAN Integration Monitoring Report, a joint report by the ASEAN Secretariat and the World Bank; two recent publications of the ASEAN Secretariat: the ASEAN Annual Report 2013-2014, and Thinking Globally, Prospering Regionally ASEAN Economic Community 2015; and various news releases, and other analyses such as Plummer and Chia (2009).

\section{REALIZING THE ASEAN ECONOMIC COMMUNITY: OBSTACLES, CHALLENGES, AND POSSIBLE SOLUTIONS}

\section{A. Pillar 1: Single Market and Production Base}

Pillar 1 aims to create a single market and production base and consists of five elements: (i) free flow of goods, (ii) free flow of services, (iii) free flow of investments, (iv) free flow of capital, and (v) free flow of skilled labor. Pillar 1 essentially forms the core of the AEC, and there have been a number of noteworthy achievements under this pillar. However, recent analysis by the McKinsey Global Institute (MGI 2014) shows that success across the five elements of Pillar 1 has been very uneven (see table below). 


\title{
Progress on ASEAN Economic Integration by Sector ${ }^{1}$
}

\author{
Progress (\%)
}

\begin{tabular}{|c|c|c|c|c|c|c|c|c|c|c|c|c|c|c|}
\hline & \multicolumn{2}{|c|}{ Tariffs } & \multicolumn{2}{|c|}{ Nontariff measures } & \multicolumn{5}{|c|}{ Trade Procedures } & \multicolumn{3}{|c|}{ Services } & \multirow[b]{2}{*}{ Average } & \multirow[b]{2}{*}{ Lowest } \\
\hline & $\begin{array}{l}\text { Tariffed } \\
\text { goods }\end{array}$ & $\begin{array}{l}\text { Tariffed } \\
\text { amount }\end{array}$ & $\begin{array}{c}\text { Standards } \\
\text { and } \\
\text { regulations }\end{array}$ & $\begin{array}{c}\text { Other } \\
\text { nontariff } \\
\text { measures }\end{array}$ & $\begin{array}{c}\text { Single } \\
\text { window } \\
\text { status }\end{array}$ & $\begin{array}{c}\text { Single } \\
\text { window } \\
\text { trade }\end{array}$ & Customs & $\begin{array}{l}\text { Trade } \\
\text { Speed }\end{array}$ & $\begin{array}{c}\text { Trade } \\
\text { cost }\end{array}$ & $\begin{array}{c}\text { Services } \\
\text { restrictiveness }\end{array}$ & $\begin{array}{c}\mathrm{FDI} \\
\text { restrictions }\end{array}$ & $\begin{array}{c}\text { Labor } \\
\text { mobility }\end{array}$ & & \\
\hline $\begin{array}{l}\text { Agriculture, } \\
\text { fisheries }\end{array}$ & 91 & 88 & 57 & 70 & & & & & & & 71 & & 75 & 57 \\
\hline Rubber & 93 & 98 & 98 & 96 & & & & & & & 71 & & 82 & 58 \\
\hline Wood & 94 & 99 & 96 & 75 & & & & & & & 68 & & 80 & 58 \\
\hline Textiles & 96 & 99 & 99 & 73 & & & & & & & 81 & & 82 & 58 \\
\hline Auto & 94 & 94 & 94 & 39 & & & & & & & 81 & & 77 & 39 \\
\hline Electronics & 98 & 99 & 57 & 62 & & & & & & & 81 & & 76 & 57 \\
\hline Consumer & 94 & 99 & 60 & 56 & & & & & & & 81 & & 76 & 56 \\
\hline Resources $^{3}$ & 84 & 93 & 79 & 89 & 70 & 58 & 61 & 85 & 94 & & 61 & & 78 & 58 \\
\hline Airtravel & & & & & & & & & & 71 & 61 & & 66 & 61 \\
\hline E-ASEAN ${ }^{4}$ & & & & & & & & & & 60 & 47 & $\mathrm{na}^{5}$ & 54 & 47 \\
\hline Health care & & & & & & & & & & 33 & 83 & 10 & 42 & 10 \\
\hline Tourism & & & & & & & & & & 71 & 90 & 30 & 64 & 30 \\
\hline Logistics & & & & & & & & & & 46 & 94 & & 70 & 46 \\
\hline Finance & & & & & & & & & & 59 & 64 & & 62 & 59 \\
\hline Telecom & & & & & & & & & & 60 & 47 & $\mathrm{na}^{5}$ & 54 & 47 \\
\hline Average & 93 & 96 & 80 & 70 & 70 & 58 & 61 & 85 & 94 & 57 & 72 & 20 & 69 & 20 \\
\hline
\end{tabular}

ASEAN = Association of Southeast Asian Nations, FDI = foreign direct investment.

Notes:

'Based on assessments of Indonesia, Malaysia, the Philippines, Thailand, and Viet Nam. Brunei Darussalam, Cambodia, the Lao People's Democratic Republic, and Myanmar are excluded due to lack of comprehensive data. ${ }^{2}$ Includes administrative charges, certificates of approval, import licensing, quantity control measures, internal taxes, and prohibition measures.

Includes mining, and oil and gas.

${ }^{4}$ Digital readiness through connectivity, local content, e-commerce, common marketplace for ICT goods and services, skills development, and e-governance.

Sectors not covered in mutual recognition agreements.

Source: McKinsey Global Institute 2014. 
In addition, a 2013 survey conducted by MGI reveals that $38 \%$ of multinational companies operating in Southeast Asia believed customs procedures were not at all uniform across the region, while more than half felt there had been little progress on smoothing out cross-border regulations governing traded services. The same survey also revealed the five sectors perceived to have the lowest degree of harmonization across ASEAN's borders: media and marketing, property and construction, commodities and energy, consumer goods, and health care and pharmaceuticals.

\section{Free Flow of Goods}

The greatest success under Pillar 1 has been in tariff reduction. Following the implementation of the ASEAN Free Trade Area (AFTA) and the adoption of the ASEAN Trade in Goods Agreement (ATIGA), common effective preferential tariff rates between the ASEAN-6 (Brunei Darussalam, Indonesia, Malaysia, the Philippines, Singapore, and Thailand) fell to virtually zero. As a result, more than $70 \%$ of intra-ASEAN trade incurs no tariff and less than $5 \%$ is subject to tariffs above $10 \%$.

Many of the achievements reported in Pillar 1 relate to tariff liberalization and other "low hanging fruit" reforms. With the bulk of intra-ASEAN trade now tariff-free, what remains are the more politically sensitive areas of reform, such as opening up economically sensitive sectors like agriculture, steel, and motor vehicles.

Moreover, while most ASEAN countries have complied with tariff reductions under AFTA/ATIGA, utilization of the common effective preferential tariffs has been relatively low. The World Trade Organization (WTO) (2011), for instance, estimates that preferential trade only accounts for $20 \%$ of intra-ASEAN trade, with the majority of trade taking place under most favored nation (MFN) tariffs.

There are several reasons for this. The first are difficulties complying with rules of origin. Although the $40 \%$ value-added rule may seem straightforward on paper, in reality, many members are unable to comply due to the high level of product fragmentation in the region, the high import content of major export products, and the administrative costs of proving origin. Furthermore, the margin of preference on most of these tariff lines is either zero or very low, taking away much of the incentive to use them (Menon 2013a and CARI 2013a).

Another possible reason is the lack of progress in reducing nontariff barriers (NTBs) to intraASEAN trade. These NTBs are increasingly replacing tariffs as protective measures. Foremost among the factors contributing to the slow progress in tackling NTBs is the difficulty in identifying which nontariff measures (NTMs) are barriers to trade. Effectively reducing NTBs will require several measures, such as giving NTBs a common definition, involving the private sector in identifying NTBs, subjecting all nontariff measures to a compliance review to ensure that they are transparent and nondiscriminatory, and maximizing the use of information communications technology (ICT) for reporting, monitoring, and eliminating NTBs (Austria 2013). NTBs are not only wide-ranging, they can evolve over time, often in response to efforts to curtail them, and therefore, present a formidable challenge to countries pursuing reform.

Some steps are already being taken to spur action on NTBs. The ASEAN NonTariff Measures (NTMs) database is being realigned with the new United Nations Conference on Trade and Development (UNCTAD) classification, and each Member State has established an interagency body at the national level to complement regional initiatives on NTMs. The AFTA Council has also endorsed 
the National-level and Regional-level Work Programme on NTMs, which will help guide ASEAN Member States in addressing NTBs at the national level (ASEAN 2014a).

ASEAN is also working on the adoption of Mutual Recognition Agreements (MRAs) in goods to prevent product-related standards and regulations from becoming technical barriers to trade. Sectors which have been identified for MRAs include pharmaceutical, cosmetic, electrical, and telecommunication products. Progress reported by the ASEAN and World Bank (2014) include the MRA on Good Manufacturing Practice of Inspection of Manufactures of Medicinal Products, translation of the ASEAN Cosmetic Directive into national legislation and the establishment of a notification system for the placement of cosmetic products, endorsement of the ASEAN Regulatory Framework on Traditional Medicines and Health Supplements, the MRA on Electrical and Electronic Equipment, and ratification of the ASEAN Harmonized Electrical and Electronic Equipment Regulatory Regime.

It is important to stress the role of trade facilitation in bringing down trade costs further. The Economic Blueprint covers several aspects of trade facilitation, including the harmonization and standardization of trade and customs procedures; customs modernization; integration of national single windows (NSWs) into an ASEAN single window (ASW); and harmonization of standards, technical regulations, and conformity assessment procedures. ATIGA also addresses trade facilitation challenges by including the ASEAN Framework on Trade Facilitation. This subsequently led to the adoption of the Trade Facilitation Work Program for the period 2009-2015. A number of agreements on transport facilitation and connectivity complement these initiatives, such as the ASEAN Framework Agreement on the Facilitation of Inter-State Transport, the ASEAN Framework Agreement on Multimodal Transport, and the Master Plan on ASEAN Connectivity.

There are positive developments worth highlighting. ASEAN members have formally adopted a Customs Code of Contact, the ASEAN Harmonized Tariff Nomenclatures, and the WTO's mode of customs valuation. NSWs-a one-stop shop to speed customs clearance-have gone live in the ASEAN-6, and ASEAN-6 plus Viet Nam have tested the preliminary exchange of trade data and information through the ASW. The pilot program for the ASEAN Self-Certification System has also been launched; this will allow certified exporters to self-certify whether their exports meet the origin requirements in export documents and should be helpful, particularly to small and medium enterprises (ASEAN 2014b and 2014c).

Work on developing the ASEAN Customs Transit System (ACTS pilot) also commenced in October 2014. The ACTS is meant to facilitate the movement of transit goods by road within ASEAN. The ACTS will be piloted in Malaysia, Singapore, and Thailand. Development will take 18 months, followed by testing from April to October 2016 (ASEAN 2014d).

While these recent initiatives have helped trade facilitation reforms move forward, data on trade costs and logistics continue to show considerable variation in trade facilitation and logistical performance across ASEAN members (Menon 2013c). Private sector feedback from several members continues to cite excessive and time-consuming documentation requirements as well as irregular and arbitrary payments for expediting customs procedures. There have also been delays and unevenness in implementing key reforms, such as integrating NSWs into the ASW-with Cambodia, the Lao People's Democratic Republic (Lao PDR), and Myanmar lagging behind-and the rest in various stages of implementation (ERIA 2012a). These challenges, coupled with the nonbinding nature of certain commitments - such as those under the 2005 Agreement and 2006 Protocol on the ASW (Dosch 2013) - make it unlikely that deadlines under the AEC will be met. For ASEAN to meet its AEC trade 
facilitation objectives, members will have to expedite the harmonization of business processes and data elements as well as address legal issues. Adopting clear timelines and trade facilitation performance targets to measure progress will also be helpful (ERIA 2012b).

\section{Free Flow of Services}

The services sector is becoming increasingly important as a driver of growth in the region, both as a share of GDP, and of employment. Given difficulties with measurement, there is increasing recognition that its share in GDP and trade is probably much higher than reported.

Despite the growing importance of the services sector, trade in services has seen less liberalization, partly because it has a much shorter history than trade in goods and is harder to grasp. There are some achievements worth mentioning. ASEAN has agreed on MRAs or their equivalent for three types of goods and eight professions (architecture, accountancy, surveying, engineering, medical practitioners, dental practitioners, tourism, and nurses) as well as concluding a "framework agreement" on MRAs (Severino and Menon 2013). The 8th Package of Services Commitments under the ASEAN Framework Agreement on Services (AFAS) was completed in 2012, and efforts are being taken to conclude the 9th Package of Services Commitments this year. Negotiations for the 6th Package of commitments on financial services have been concluded (ASEAN 2014a). Progress notwithstanding, the number of services covered by existing agreements needs to be expanded, and agreements need to be implemented in ways that improve mobility for skilled labor.

In principle, the liberalization of services under the AFAS and the Economic Blueprint should have been significantly bolder than under the WTO's General Agreement on Trade in Services (GATS). In reality, however, ASEAN service liberalization has been slow. Existing commitments are insufficient. Nevertheless, AFAS commitments have improved over time, and now, there are significant GATS-plus elements that have been adopted (Hamanaka 2013).

Liberalization-particularly in banking and financial services-has been hampered by built-in flexibilities introduced under the "ASEAN-X" formula, which allows member states to liberalize according to each country's readiness. In financial services, therefore, the scope of liberalization is not specified, and member countries are allowed to carve out subsectors that they are not ready to liberalize (Nikomborirak and Jitdumrong 2013).

In addition to these flexibilities, statutory or constitutional limitations on foreign equity, restrictions on land ownership, and domestic impediments to professional or labor mobility, such as work permits and examinations, continue to work against fulfilling services liberalization commitments (Severino and Menon 2013). This partly explains why only the MRAs for engineers, architects, and nurses have had any discernible (albeit limited) impact. These problems have been compounded by the global tendency to liberalize services last (Hill and Menon 2013).

Nevertheless, liberalizing services trade could be improved by concentrating on groups of services rather than focusing on isolated individual sectors, prescribing standard rules governing licensing and other regulatory regimes, and replacing built-in flexibilities under the ASEAN-X formula with specified dates for compliance (Nikomborirak and Jitdumrong 2013). 


\section{Free Flow of Investments and Capital}

A key objective of AFTA was to remove barriers to trade in order to further promote foreign direct investment (FDI) in regional production networks. Prior to the adoption of the ASEAN Comprehensive Investment Agreement (ACIA) in 2008, the scope of the ASEAN Investment Area had placed too much emphasis on intraregional FDI-prioritizing investment facilitation and provision of national treatment among ASEAN partners. This strategy made very little sense, given that the bulk of FDI in the region comes from non-ASEAN economies like the United States (US), Japan, the European Union (EU), and increasingly, the People's Republic of China (PRC), and the Republic of Korea. ACIA and the Economic Blueprint seem to have gone some ways toward fixing this by covering a wider range of provisions on investment liberalization, MFN and national treatment, investment protection, facilitation and cooperation, and promotion and awareness (Aldaba and Yap 2009). The ASEAN Economic Ministers also recently signed the Protocol to Amend the ACIA, which lays out the process and prescribed timelines for modifying and amending investment reservations (ASEAN 2014e).

A number of other initiatives have helped facilitate capital flows in the region, such as the Asian Bond Markets Initiative, the 2011 Credit Guarantee and Investment Facility), and the $\$ 240$ billion Chiang Mai Initiative Multilateralized (CMIM) swap arrangements, which is supported by a strengthened ASEAN+3 Macroeconomic Research Office (AMRO).

The formation of the ASEAN Exchanges involving the ASEAN-5 and Viet Nam should be a major step toward further liberalizing capital flows and offering more opportunities to investors across the region. The ASEAN Exchanges have launched the ASEAN Trading Link, a gateway for securities brokers to offer investors easier access to participating exchanges (ASEAN 2014b). In addition, the Securities Regulators of Malaysia, Singapore, and Thailand have signed a Memorandum of Understanding (MOU) to establish and implement the ASEAN mutual recognition framework for mutual funds (ASEAN 2014a).

Nonetheless, as with trade in goods as well as in services, unilateral policy initiatives seem to have played a more significant role in investment and financial liberalization. Key challenges also remain, foremost being the removal of domestic hurdles that continue to hamper ASEAN integration. To increase investments, priority must be given to improving the business climate and reducing the cost of doing business in each country (Bhaskaran 2013). The real impact of the AEC on FDI will depend on the extent to which it succeeds in presenting the region to potential investors as a single market and production base.

\section{Free Flow of (Skilled) Labor}

Attempts to liberalize skilled labor within ASEAN could be positive if it results in greater mobility of professionals within the region, reducing skills gaps. Unlike reforms relating to trade and investment, however, policies relating to labor flows remain piecemeal. Although ASEAN labor markets are becoming increasingly integrated, policies relating to cross-border movement of people continue to lag behind. The policy gaps relating to labor flows exist in both sending and receiving countries, and both must be addressed. Therefore, the policy challenges relate to the governance of labor mobility, the protection of migrant workers, and harnessing labor migration for economic development.

Although ASEAN has signed several formal accords since 2000-including the January 2007 ASEAN Declaration on the Protection and Promotion of the Rights of Migrant Workersimplementation has been lackluster (Hill and Menon 2012). However, intra-ASEAN labor flows occur 
independently of these arrangements and are largely market-driven-dictated by large intercountry differences in labor supply and demand, wage differentials, and porous borders.

In September 2014, the ASEAN Economic Ministers and the ASEAN Education Ministers endorsed the ASEAN Qualification Reference Framework (AQRF), which will enable comparisons of qualifications of skilled labor and provide a standard for cross-referencing among the different National Qualification Frameworks across ASEAN Member States. Each country is expected to voluntarily comply with the AQRF according to their own capacity and start the referencing process by 2016 and at the latest by 2018 (ASEAN 2014c and 2014f).

While the AQRF may help facilitate cross-border flows of skilled labor, the overwhelming share of both recorded and unrecorded labor flows within ASEAN is in low- and semi-skilled labor. This extends from domestic helpers in Malaysia and Singapore (from the Philippines and Indonesia), to agricultural labor in Malaysia (from Indonesia) and Thailand (from Cambodia, the Lao PDR, and Myanmar) to various service sectors, such as construction in Malaysia and Singapore, and food processing in Thailand. It is unclear what impact the AEC will have on overall flows as it only deals with the movement of skilled labor. There are clear difficulties and sensitivities in liberalizing unskilled labor flows given the diversity within ASEAN. But it remains an open question as to how an economic community, however defined-or a single market and production base-can be achieved when the majority share of labor is excluded.

Nevertheless, the attempt to liberalize skilled labor within ASEAN could be a positive move if it results in greater mobility of professionals within the region that will reduce skills gaps. This is being pursued by negotiating ASEAN MRAs. The approach being taken has generally been bilateral, given the complexities involved. Although MRAs underscore ASEAN's commitment to the principle of regional economic integration, most are riddled with loopholes under the general cover of "flexibility," and some of them have not been ratified by all ASEAN Member States (Severino and Menon 2013). Furthermore, an MRA does not provide for unrestricted free flow of foreign professionals because relevant domestic regulations and market demand conditions still apply. It remains to be seen how much these MRAs will add to skilled labor movements that were already taking place bilaterally.

\section{B. Pillar 2: Highly Competitive Economic Region}

Two of the key components of the AEC's second pillar are competition policy and intellectual property rights (IPR) protection, both of which aim to improve a country's business environment. Both promote price, product, and production-process competition, thus lowering production and transaction costs, and encouraging more efficient allocation of resources and improved consumer welfare. Effective IPR protection also helps foster competition among firms, leading to greater product and process innovation, making consumers better off. They are also designed to better the business climate in attracting FDI inflows (Severino and Menon 2013).

Five ASEAN Member States (Indonesia, Malaysia, Singapore, Thailand, and Viet Nam) have comprehensive competition policies and laws, while the remaining ASEAN Member States have intensified their efforts to introduce competition policy and law by 2015 (ASEAN 2014a and 2014b). The ASEAN Experts Group on Competition (AEGC) is already working on new targets and a regional plan of action on competition post-2015. The draft Competition Action Plan is expected to be finalized during the 14th AEGC Meeting in November 2014 (ASEAN 2014g). Meanwhile, the ASEAN Working Group on Intellectual Property Cooperation (AWGIPC) has commissioned a study to assess 
the implementation of the ASEAN IPR Action Plan 2011-2015, while an ad hoc Task Force on Trade Marks has been established to ensure the completion of the Trade Marks related action lines by 2015.

Despite these steps, competition policy and IPR are difficult areas of reform. Enforcing intellectual property rules, in particular, has been a major concern with respect to developing countries (Konan et al. 1995). Although the Economic Blueprint bears the commitment to integrate the regional economy, both competition policy and IPR protection are essentially national in application. In light of widely different levels of development among ASEAN members and their often clashing national interests, cooperation and coordination - rather than uniformity in competition and IPR rules-are likely to be more achievable as goals. Even these, however, will likely take considerable time (Lall and McEwin 2013).

We can expect more achievements in another core element of Pillar 3, infrastructure development. ASEAN (2014b) reports some notable progress in terms of building physical infrastructure: (i) the designated roads and highways of the member states forming the ASEAN Highway Network (AHN) are being physically connected, and road and numbering signs along the Network's priority Transit Transport Routes (TTR) have already been installed in order to enhance safety and comfort of road users; (ii) six out of the planned 16 cross-border interconnections of the ASEAN Power Grid (APG) have already been put into operation; and (iii) 11 bilateral pipeline connections with a total length of 3,020 kilometers have been established under the Trans-ASEAN Gas Pipeline (TAGP), which aims to connect the gas pipeline infrastructure of ASEAN Member States. In telecommunications, efforts are being taken to reduce international mobile roaming rates within ASEAN, and Malaysia and Singapore have been the first to sign a bilateral agreement to reduce the mobile roaming rates charged by their respective telecommunication providers (ASEAN 2014b).

However, these gains in infrastructure development are likely to be tempered by remaining bottlenecks in the area of transport liberalization. ASEAN has targeted the creation of an ASEAN Single Aviation Market by 2015. The ASEAN Member States have already signed the ASEAN Multilateral Agreement on Air Services and the ASEAN Multilateral Agreement on the Full Liberalization of Passenger Air Services, but ratification of these agreements is still pending in some ASEAN Member States (ADBI 2014). Progress in the maritime sector is even more limited, though this is probably not surprising as this is not a priority sector under the AEC (ASEAN and World Bank 2014).

\section{Pillar 3: A Region of Equitable Economic Development}

The third pillar of the Economic Blueprint is equitable economic development, which aims to address the development divide and accelerate integration of Cambodia, the Lao PDR, and Myanmar within ASEAN. Disparities are inconsistent with the idea of economic community, however conceived.

There is evidence that the process of convergence has begun as newer members begin to catch up to the economic conditions in the original, higher income ASEAN states. Strong rates of economic growth since the 1990s-driven by trade, investment, and other market reforms-have reduced differences in per capita incomes. This rapid growth has also been associated with dramatic reductions in poverty. Still, much more needs to be done before the development divide is substantially narrowed (Menon 2013c).

A key component of Pillar 3 involves strengthening small and medium enterprises (SMEs) in ASEAN through flagship projects under the Strategic Action Plan for ASEAN SME Development (2010-2015). Thirty business incubators and innovation centers have been established and make up 
the ASEAN Business Incubator Network (ABINet) to promote business matching and development. In addition, the ASEAN SME Guidebook towards the AEC 2015 has been developed to enhance awareness of the financial facilities and market opportunities available for ASEAN SMEs (ASEAN 2014b). There is also an initiative to establish an "ASEAN Online SME Academy," which will serve as a single access point to business information and training resources to support ASEAN SMEs (ASEAN 2014h).

Other components of Pillar 3 are the ASEAN Framework for Equitable Economic Development (AFEED) adopted in 2011, and subregional arrangements such as the Initiative for ASEAN Integration (IAI). Implementation of AFEED has begun with the development of a quantitative tool that will monitor progress in realizing AFEED's principles and identify appropriate policy measures (ASEAN 2014a).

The lack of disaggregated data makes it difficult to discern how much success or failure can be attributed solely to subregional initiatives such as the IAI. But an assessment of the IAI and four Subregional Zones (SRZs) - the Singapore-Johor-Riau (SIJORI) zone, the Greater Mekong Subregion (GMS), the Indonesia-Malaysia-Thailand Growth Triangle (IMT-GT), and the Brunei DarussalamIndonesia-Malaysia-Philippines East ASEAN Growth Area (BIMP-EAGA)-affirms that subregional zones can potentially help reduce development gaps and improve connectivity across national boundaries. To fully harness the potential of these initiatives, emphasis should be placed on developing the newer and less-developed ASEAN members with innovative ways of financing, such as public-private partnerships (Pomfret and Das 2013).

Nonetheless, the reality is that neither the IAI nor other subregional initiatives will have the resources, or the ability, to fully address the development divide. In ASEAN, unlike in Europe, the rich members are too small to be able to provide the kind of resources required to significantly affect the process of narrowing development gaps. While such initiatives may be helpful, progress must come from within the newer members themselves as they institute broad economic reforms that promote trade and investment-as they have been doing. Among other things, investing in social infrastructure, especially in education and health-to produce a more productive workforce, to increase capital inflows and labor absorption using comparative advantage, and to redress asset inequality and enhance incentives for productivity in agriculture-are all necessary conditions. They need to be complemented with the other elements of an inclusive growth strategy in order to ensure convergence (Menon 2013b).

\section{Pillar 4: Integration into the Global Economy}

The fourth pillar of full integration into the global economy has seen some of the greatest strides, which has enabled a thriving "Factory ASEAN." Throughout the 1980s and 1990s, ASEAN members embarked on a combination of multilateral and unilateral measures to reduce barriers to trade in goods, services, and investments. These measures have made ASEAN one of the most globally integrated regions in the world. According to the MGI Connectedness Index-which measures countries' integration into the global economy based on their inflows and outflows of goods, services, finance, people, and data and communication-five ASEAN countries rank among the world's 50 most connected nations: Singapore (ranked fourth), Malaysia (18th), Thailand (36th), the Philippines (45th), and Viet Nam (48th) (MGI 2014). Clearly, ASEAN's long-standing commitment to openness is one of its defining features and needs to be burnished to sustain and advance regionalism in Southeast Asia. 
Progress to date underlines how liberalization has been driven more by market forces and unilateral actions than by regional agreements. Since 2000, however, there has been less progress on multilateral liberalization, and domestic reform has slowed significantly as a result. One partial response has been the proliferation of ASEAN FTAs (ADB 2013). ASEAN's FTAs have done little to promote regional economic integration or integration with the wider Asian or the global economy.

A closer look at ASEAN's FTAs leads to several conclusions. One is that the shift from unilateral liberalization to preferential liberalization has not led to further external opening or domestic reform (WTO 2011). Another is that the FTAs are "weak" and "trade-light." In other words, while the agreements commit the parties to eliminate tariffs on trade between themselves, they do not effectively address regulatory and other NTBs, like product standards and MRAs, services, investment, IPRs, government procurement, or the movement of business people-which are all more important than tariffs for regional economic integration. Thus, the FTAs that ASEAN has concluded hardly promoted regional economic integration or ASEAN's integration with the wider Asia or the global economy (Sally 2013 and Hamanaka 2012).

These findings are significant, particularly in light of the Regional Comprehensive Economic Partnership (RCEP), an FTA across ASEAN+6 (the 10 ASEAN members plus Australia, the PRC, Japan, the Republic of Korea, India, and New Zealand). Although RCEP membership is supposed to be based on open accession, it starts with the 10 ASEAN members and the "Plus Six," all of whom have bilateral FTAs with ASEAN (ASEAN+1 FTAs).

The RCEP is one of a series of mega-regional trade agreements currently under negotiation including the Trans-Pacific Partnership (TPP) and the US-EU FTA (the Transatlantic Trade and Investment Partnership). Since its launch in November 2012, RCEP has concluded five rounds of negotiations, and the ASEAN Economic Ministers have reported negotiating progress on trade in goods, trade in services and investment, economic and technical cooperation, intellectual property, competition, and legal and institutional issues (ASEAN 2014c). If implemented, RCEP could create the world's largest trading bloc with potentially significant economic gains for the countries involved. Also significant, in the geopolitical battle to shape the future of regional trade rules and standards, RCEP includes the PRC but not the US.

The RCEP faces some key challenges if it is to live up to its potential. Details remain sparse, but what we do know from RCEP's Guiding Principles is that it will add to, rather than replace, existing ASEAN+1 FTAs while at the same time introducing "significant improvements" over these agreements. There is, however, an important qualifier in the dreaded "flexibility" clause: "RCEP will include appropriate forms of flexibility including provision for special and differential treatment, plus additional flexibility to the least developed ASEAN Member States.".

Flexibility could be a boon or bane for the RCEP. While it could help break deadlocks and protect disparate national interests, it could also limit change or curtail progress in achieving greater liberalization. Indeed, there is much to negotiate - and many breakthroughs needed - if RCEP is to supersede existing agreements.

The existing five ASEAN+1 and 23 ratified bilateral FTAs vary greatly in terms of almost everything up for negotiation. One example is rules of origin (ROOs), which determine the country of origin of products and in turn their eligibility for preferential treatment in international trade. There are at least 22 different ROOs among ASEAN+1 FTAs, even after aggregating those that are similar but not the same. Only about $30 \%$ of tariff lines across the ASEAN+1 FTAs share common ROOs. With 
bilateral agreements - the Japan-India FTA for instance - there are 12 types of ROOs, seven of which are unique from the ASEAN+1 FTAs. The sheer number of ROOs - and their lack of commonality across FTAs - will make the task of harmonizing and consolidating them that much harder.

Proponents of FTAs argue that deeper agreements can be achieved more rapidly on difficult issues when there are only a small number of negotiating partners involved. But many advocates fail to explain how this principle works within the context of FTA consolidation, where parties are essentially reversing the negotiation process and adding more countries. If access to a bigger market is the lure, then wouldn't the Doha Round be a better, if not easier, process? It may be better. But we know it is not easier. In truth, consolidation may be just as difficult, if not more difficult, than simply starting from scratch. Getting a pair of countries to agree on a specific set of terms will not necessarily facilitate similar breakthroughs with third parties. To ignore this is to ignore ground realities and the political economy of FTA negotiations. And anyone who has looked closely at an FTA will know how difficult the task of enmeshing even two similar agreements can be, let alone many different ones.

But consolidate they must, if an RCEP is to eventually emerge. With RCEP, there is also the real risk of a "race to the bottom," where the least common denominator prevails to secure consensus (Menon 2013b). Were this to occur, RCEP would simply add to the tangled regional trade landscape. If a race to the bottom or minimal change comes about, then the RCEP will be largely redundant. Although cumulation rules may expand through increased membership, this usually amounts to little when product fragmentation trade is significant. Changing the type of ROO is more important, but also more difficult. The South Asia Free Trade Agreement (SAFTA), a failed attempt at consolidation, illustrates this. Most trade within South Asia continues under more generous bilateral FTAs or under MFN rates. Sadly, SAFTA's main contribution has been to add another strand to the global spaghetti bowl.

Will the same fate befall RCEP? Unless there is enough political will to close potential loopholes disguised as "flexibility" and pursue reforms deeper than those ever before attempted, RCEP's future as a consolidated bloc remains uncertain. RCEP faces many challenges but this is the fundamental one. A meaningful RCEP will require a resolve similar to that which gave birth to the EUan example of a successful FTA consolidation, if nothing else. Unless this happens by its looming 2015 deadline, RCEP may be seen as serving the geopolitical interests of a few players, with little economic effect.

In this environment, one way forward is to return to the most widely used modality of trade liberalization-unilateral action - but this time involving the multilateralization of preferences rather than unreciprocated reductions in tariff rates. In Asia, ASEAN's original members have done this with the AFTA. Evidence cited in the joint ASEAN and World Bank report (2014) confirms that AFTA has been trade creating rather than trade diverting. First, tariff liberalization under AFTA has led to a faster decline in external tariffs - if an imported product faced a 10\% MFN tariff and 0 tariff under AFTA, then the ASEAN importing country would subsequently tend to reduce its MFN tariff on that product between 2.5 and 4.5 percentage points. Second, products receiving preferential treatment in Indonesia, the Philippines, and Thailand underwent greater reduction in MFN tariffs than nonpreferential products between 1 and 5 percentage points. Third, an expansion in intra-ASEAN trade did not lead to a decline in ASEAN's trade with the rest of the world; on the contrary, trade with the rest of the world expanded proportionately.

RCEP countries could follow suit since more than three-fourths of most countries' imports are already covered or soon to be covered by an FTA. There is little point in holding out to negotiate 
reciprocity with the countries accounting for the small amount of trade that remains uncovered. Also, the benefits from reciprocity fall short of multilateralization when preference utilization is low. The political economy suggests that the resistance from FTA partners towards multilateralization decreases as the number of FTAs increase, due to preference erosion.

While multilateralization is easily applied to tariffs, it is also naturally suited to NTBs and difficult sectors such as services. The removal of many NTBs share public good characteristics. Unlike tariffs, it is either costly or impractical to exclude nonmembers once an NTB has been removed. Similarly, if services liberalization is pursued through harmonizing standards or regulatory convergence, rather than mutual recognition arrangements, nonmembers can easily accede later. Multilateralization of preferences, whether tariff or nontariff, is a strategy that might recommend itself to negotiators who are charged with the responsibility of delivering RCEP by 2015.

\section{Engaging the Private Sector and the Broader Community}

Each of the four pillars presents a demanding set of challenges to be met before the AEC can be fully realized. One challenge that cuts across the four pillars is achieving greater engagement with the private sector and the broader community. The AEC may be led by governments, but it cannot succeed without fully engaging business and the public at large. But it seems that efforts to prepare the private sector have enjoyed negligible success and public awareness is equally abysmal.

The three waves of the ASEAN-Business Advisory Council (BAC) Survey on ASEAN Competitiveness, conducted by the ASEAN Business Advisory Council since 2010, has consistently revealed consultation with businesses and dissemination of information on AEC initiatives as the least satisfactory areas rated by businesses. In the 2013 ASEAN-BAC survey, respondents were asked about their familiarity with the details of ASEAN policy initiatives that were related to trade and investments such as the AFTA and the AEC. Around 60\% indicated that they had at least general knowledge of these initiatives, while $32 \%$ reported having limited knowledge. Only $2 \%$ of the respondents reported having detailed knowledge of these initiatives. Likewise, in a recent business survey of firms in nine ASEAN member countries (excluding Malaysia), commissioned as part of an $A D B$ study, $55 \%$ of the respondents reported being unaware of the AEC; it was more likely for respondent firms to be aware of the ASEAN-PRC Trade Agreement than of the AEC (Das et al. 2013).

Other estimates report that less than one-fifth of ASEAN businesses have made any plans for the end of 2015 (CARI 2013a). In contrast, 54\% of senior business leaders from US companies covered in the most recent ASEAN Business Outlook Survey said that their company has a strategy based on the goals of the AEC (AmCham Singapore and US Chamber of Commerce 2014).

Domestic and small firms are more likely to feel worried by greater integration-the ASEANBAC survey revealed that the bigger the firm and the higher the level of foreign ownership, the greater the likelihood that integration would be seen as an opportunity, rather than a threat.

Enfranchisement mechanisms to promote greater civil society involvement, through nongovernment organizations (NGOs) and civil society organizations, are even more limited. This translates into an even greater lack of awareness or preparation among the general populace.

All of these findings are consistent with the results of the ASEAN's own Survey on ASEAN Community Building Effort 2012, which revealed that (i) the overall level of understanding among businesses and the general public is still low; (ii) the preparation work done by businesses and the 
general public has been minimal; and (iii) most businesses have not prepared activities related to the AEC, nor considered how the AEC would link to their company's vision. The survey also revealed concerns about the possible negative impacts of the AEC, particularly with regards to differences in overall competitiveness.

This lack of awareness and engagement needs to change quickly if the AEC is to make a difference. ASEAN has already taken a number of steps to strengthen collaboration with other stakeholders. These include the regular annual dialogues between the ASEAN Economic Ministers (AEM) and the ASEAN-BAC, and consultations with local chambers of commerce and industry associations, and foreign business councils based in the region (ASEAN 2012). But ASEAN's own Survey on ASEAN Community Building Effort 2012 revealed a persistent lack of awareness and preparedness on the part of the $\mathrm{AEC}$, and quite rightly recommended building stronger partnerships with civil society organizations and industry groups.

ASEAN needs to encourage greater and more regular private sector feedback, through initiatives such as the ASEAN-BAC survey, to assess the impact and effectiveness of AEC measures. ASEAN could also invite businesses to contribute to regular reviews of ASEAN achievements on integration, such as the AEC Scorecard, which is currently a government-produced evaluation (Nesadurai 2013). Independent assessments by the private sector can help improve the effectiveness of existing implementation and gather business views on critical impediments to the AEC. One recent initiative would be the Network ASEAN Forum (NAF), convened by the ASEAN Business Club in cooperation with the CIMB ASEAN Research Institute (CARI). The NAF's inaugural gathering in 2013 convened around six "Lifting-the-Barriers Roundtables," focusing on identifying bottlenecks and barriers to free trade in six sectors: aviation, connectivity, infrastructure, power and utilities, capital market, financial services and healthcare. The Lifting-the-Barriers Report has since been released, covering each of the six sectors (CARI 2013b).

While greater private sector involvement should be encouraged, care should be taken to ensure that this involvement ultimately protects national rather than vested interests. Governments must deal with domestic lobbies that seek to preserve market share by resisting reform or pursuing new protectionist measures, in the guise of promoting the national interest. This is not always easy to identify and distinguish, let alone deal with, and close monitoring and strong leadership will be required.

\section{BEYOND ASEAN ECONOMIC COMMUNITY 2015}

In light of the many obstacles and challenges that remain-compounded by recent events that increase risk and uncertainty-creating a fully functional AEC by the end of 2015 seems nigh impossible. As such, it would be best to view 2015 as a milestone rather than a "must-do" target. The real test for the AEC will lie in the years beyond. ASEAN has already begun the process of crafting the post-2015 agenda, a key priority of which is strengthening implementation of the Economic Blueprint to close remaining gaps (ASEAN 2014c).

Recent studies highlight the potential gains of fully implementing the commitments under the Economic Blueprint. An ADB-ILO study (2014) estimates that full implementation of the AEC could (i) raise the region's GDP growth by $7.1 \%$ above the baseline forecast; and (ii) generate an additional 14 million jobs in six ASEAN economies (Cambodia, Indonesia, the Lao PDR, the Philippines, Thailand, and Viet $\mathrm{Nam}$ ) by 2025. The same study argues that the AEC will hasten the pace of structural change 
and potentially drive a shift from low to higher productivity sectors. Meanwhile, MGI (2014) reckons that implementation of the AEC, coupled with a shift in global manufacturing away from the PRC as a result of labor costs, could create between $\$ 280$ billion to $\$ 615$ billion in annual economic value for ASEAN by 2030 ; this would be equivalent to $5 \%-12 \%$ of ASEAN GDP in 2030 . The same study finds that in many sectors, greater integration could produce productivity benefits worth up to $20 \%$ of the cost base as well as boosting demand and creating consumer surplus.

However, this link between regional integration and productivity is not automatic. As the ADBILO study points out, "realizing this potential will depend on supportive national and regional policies-as well as on investments in public infrastructure and the skills needed for a highly productive workforce." Indeed, countries in Asia that have sustained productive growth and avoided the middle-income trap have managed to do so by upgrading the skills of their workforce, investing in more research and development, improving access to more advanced infrastructure, and diversifying their economies through industrial policy, among others (MGI 2014 and Agenor, Canuto, and Jelenic 2012).

\section{CONCLUSION}

Although ASEAN has come a long way toward realizing its goal, the veracity of the challenges that remain suggests that it will fall short of the approaching deadline. Indeed, ASEAN's latest selfassessment from March 2013, the AEC Scorecard, suggests that the region had reached only $77.5 \%$ of its AEC targets from 2008 to March 2013.

Recognizing that the deadline will be missed is important to ensure that work continues past the 2015 deadline. Indeed, many of ASEAN's working groups, task forces, and the like, seem almost preoccupied, somewhat prematurely, with a post-2015 agenda, confirming recognition of this reality. Moreover, the AEC Scorecard reveals that the pace of reform seems to have slowed down rather than picked up, partly due to having to move on to the more difficult parts of the reform agenda. Even if the pace were to pick up now, the real test for the AEC will lie in the years beyond 2015.

Apart from hitting the remaining targets, the bigger challenge of implementing the accords legitimately lies beyond the AEC deadline. This is no easy task when considering that domestic laws, or even the Constitution, may have to be amended to accommodate AEC accords. The flexibility that characterizes ASEAN cooperation and institutional arrangements, the so-called ASEAN Way, could give member states a pretext for noncompliance-and there are enforcement issues. Giving AEC commitments more teeth is the key challenge to be overcome in realizing the AEC if it is to be more than a political exercise in solidarity. We should therefore view 2015 as a milestone for the AEC rather than a hard target, and not a destination but rather as part of a journey (Severino and Menon 2013).

Finally, we must remember that the AEC is only one of the three pillars of a unified ASEAN; ASEAN Member States must also ensure progress in the other two pillars, the ASEAN PoliticalSecurity Community and the ASEAN Socio-Cultural Community. Maximizing synergies across the three pillars is just as important. For instance, the ASEAN Socio-Cultural Community's efforts to strengthen awareness of ASEAN should help increase private sector and community involvement in the AEC. More importantly, as recent disputes over property rights in the PRC have shown, progress on the economic front cannot be divorced from long-standing geopolitical issues facing some ASEAN member countries. Indeed, these events have reminded us that ASEAN was born as, and in many ways designed to be, a politico-security pact, and that the economic agenda is a more recent experiment. Given the interdependence between economics and geopolitics, however, the institution will have to 
weather the challenges that the latter poses on its cohesion if it is to progress on the former. So far, it has avoided getting involved in geopolitics without creating too much discontent among its ranks. Just how long it can continue down this path of ignorance before risking collateral damage to its structural integrity remains to be seen. 


\section{REFERENCES}

ADB. 2013. Multilateralizing Asian Regionalism: Approaches to Unraveling the Asian Noodle Bowl. The Chapter. Asian Economic Integration Monitor. Manila.

ADB and ILO. 2014. ASEAN Community 2015: Managing Integration for Better Jobs and Shared Prosperity. Bangkok, Thailand.

ADB Institute. 2014. ASEAN 2030 Toward a Borderless Economic Community. Tokyo.

Agénor, P.-R., O. Canuto, and M. Jelenic. 2012. Avoiding Middle-Income Growth Traps. 21 December. http://www.voxeu.org/article/avoiding-middle-income-growth-traps

Aldaba, R. M. and J. T. Yap. 2009. Investment and Capital Flows: Implications of the ASEAN Economic Community. Philippine Institute for Development Studies.

AmCham Singapore and US Chamber of Commerce. 2014. ASEAN Business Outlook Survey 2014.

ASEAN. 2012. Public Private Sector Engagement. Jakarta. http://www.asean.org/communities/asean -economic-community/category/public-private-sector-engagements

-_- 2014a. ASEAN Annual Report 2013-2014. Jakarta: ASEAN Secretariat.

-_- 2014b. Thinking Globally, Prospering Regionally - ASEAN Economic Community 2015. Jakarta: ASEAN Secretariat.

- - - 2014c. Key Outcomes of the 12th AEC Council Meeting, 46th ASEAN Economic Ministers' (AEM) Meeting and Related Meetings. Nay Pyi Taw, Myanmar. 25-28 August.

- - 2014d. ASEAN to Pilot Customs Transit System. News release. 6 November. http://www.asean.org/news/item/asean-to-pilot-customs-transit-system?category_id=27

- - - 2014e. ASEAN Signs Protocol to Improve Investment Regimes. News release. 1 September. http://www.asean.org/news/asean-secretariat-news/item/asean-signs-protocol-to-improve -investment-regimes

- - - 2014f. ASEAN Enhances Mobility of Skilled Labour through Qualifications Reference Framework. News release. 13 October. http://www.asean.org/news/asean-secretariat-news/ item/asean-enhances-mobility-of-skilled-labour-through-qualifications-reference-framework ?category_id=27

- - - 2014g. ASEAN Formulates a Post-2015 Vision and Strategic Action Plan on Competition. News release. 11 September. http://www.asean.org/news/asean-secretariat-news/item/asean -formulates-a-post-2015-vision-and-strategic-action-plan-on-competition?category_id=27

- - - 2014h. ASEAN SMEs to Have Online Access to Information and Training Resources Soon. News release. 5 November. http://www.asean.org/news/item/asean-smes-to-have-online -access-to-information-and-training-resources-soon?category_id=27 
ASEAN and World Bank. 2014. ASEAN Integration Monitoring Report. A Joint Report by the ASEAN Secretariat and the World Bank. Jakarta: ASEAN and Washington, DC: World Bank.

ASEAN Business Advisory Council. 2013. ASEAN-BAC Survey on ASEAN Competitiveness. Association of Southeast Asian Nations.

Austria, M. 2013. Non-Tariff Barriers: A Challenge to Achieving the ASEAN Economic Community. In S. Das, J. Menon, R. Severino, and O. Shresta, eds. The ASEAN Economic Community: A Work in Progress. Manila: ADB and Singapore: Institute of Southeast Asian Studies.

Bhaskaran, M. 2013. The ASEAN Economic Community: The Investment Climate. In S. Das, J. Menon, R. Severino, and O. Shresta, eds. The ASEAN Economic Community: A Work in Progress. Manila: ADB and Singapore: Institute of Southeast Asian Studies.

CIMB ASEAN Research Institute (CARI). 2013a. The ASEAN Economic Community (AEC): An Alternative Scorecard Approach. The Real Status of Implementation, Challenges and Bottlenecks (Research Overview).

- - . 2013b. The Network ASEAN Initiative webpage. http://www.cariasean.org/network-asean -forum/lifting-barriers-initiative/

Das, S. 2012. A Critical Look at the ASEAN Economic Community Scorecard. East Asia Forum. 1 June. http://www.eastasiaforum.org/2012/06/01/a-critical-look-at-the-asean-economic-community -scorecard/

Das, S., J. Menon, R. Severino, and O. Lal Shrestha, eds. 2013. The ASEAN Economic Community: A Work in Progress. Manila: ADB and Singapore: Institute of Southeast Asian Studies.

Dosch, J. 2013. The ASEAN Economic Community: The Status of Implementation, Challenges and Bottlenecks. Kuala Lumpur: CIMB ASEAN Research Institute.

ERIA. 2012a. Mid-Term Review of the Implementation of AEC Blueprint: Executive Summary. Jakarta.

- - - 2012b. Trade Facilitation: The Way Forward for ASEAN and Its FTA Partners. ERIA Policy Brief No. 2012-04. Jakarta.

European Union (EU). 2013. Tenth Report on Potentially Trade-Restrictive Measures. Brussels.

Hamanaka, S. 2012. Anatomy of South-South FTAs in Asia: Comparisons with Africa, Latin America, and the Pacific Islands. ADB Working Paper Series on Regional Economic Integration No. 102. Manila: ADB.

-_- 2013. Asian Free Trade Agreements and WTO Compatibility. Singapore: World Scientific.

Hill, H. and J. Menon. 2012. ASEAN Economic Integration: Driven by Markets, Bureaucrats, or Both? In M. E. Kreinin and M.G. Plummer, eds. The Oxford Handbook of International Commercial Policy. Oxford: Oxford University Press. 
- - - 2013. Southeast Asian Commercial Policy: Outward-Looking Regional Integration. In Ian Coxhead, ed. Handbook of Southeast Asian Economies. Routledge.

Konan, D., S. La Croix, J. Roumasset, and J. Heinrich. 1995. Intellectual Property Rights in the AsianPacific Region: Problems, Patterns and Policy. Asian-Pacific Economic Literature. 9 (2). pp. 13-35.

Lall, A. and R. Ian McEwin. 2013. Competition and Intellectual Property Laws in the ASEAN Single Market. In S. Das, J. Menon, R. Severino, and O. Shresta, eds. The ASEAN Economic Community: A Work in Progress. Manila: ADB and Singapore: Institute of Southeast Asian Studies.

McKinsey Global Institute (MGI). 2014. Southeast Asia at the Crossroads: Three Paths to Prosperity. November.

Menon, J. 2013a. Supporting the Growth and Spread of International Production Networks in Asia: How Can Trade Policy Help? ADB Working Paper Series on Regional Economic Integration No. 112. Manila: ADB.

- - - 2013b. The Challenge Facing Asia's Regional Comprehensive Economic Partnership. East Asia Forum. 23 June. http://www.eastasiaforum.org/2013/06/23/the-challenge-facing-asias-regional -comprehensive-economic-partnership/

- - - 2013c. Narrowing the Development Divide in ASEAN: The Role of Policy. Asia-Pacific Economic Literature. 27 (2). pp. 25-51.

Milo, M. 2013. Linkage between Greater Mekong Subregion Economic Cooperation and ASEAN Economic Community. Presentation at the Mekong Forum 2013: Towards More Inclusive and Equitable Growth in the Greater Mekong Subregion. Khon Kaen. 11-12 July. http://www.mekongforum.com

Nesadurai, H. 2013. Enhancing the Institutional Framework for AEC Implementation: Designing Institutions that are Effective and Politically Feasible. In S. Das et al., eds. The ASEAN Economic Community: A Work in Progress. Singapore: Asian Development Bank/ Institute of Southeast Asian Studies.

Nikomborirak, D. and S. Jitdumrong. 2013. ASEAN Trade in Services. In S. Das, J. Menon, R. Severino, and O. Shresta, eds. The ASEAN Economic Community: A Work in Progress. Manila: ADB and Singapore: Institute of Southeast Asian Studies.

Plummer, M. and C. Siow Yue, eds. 2009. Realizing the ASEAN Economic Community: A Comprehensive Assessment. Singapore: Institute of Southeast Asian Studies.

Pomfret, R. and S. Das. 2013. Subregional Zones and ASEAN Economic Community. In S. Das, J. Menon, R. Severino, and O. Shresta, eds. The ASEAN Economic Community: A Work in Progress. Manila: ADB and Singapore: Institute of Southeast Asian Studies.

Sally, R. 2013. ASEAN FTAs: State of Play and Outlook for ASEAN's Regional and Global Integration. In S. Das, J. Menon, R. Severino, and O. Shresta, eds. The ASEAN Economic Community: A Work in Progress. Manila: ADB and Singapore: Institute of Southeast Asian Studies. 
Severino, R. and J. Menon. 2013. The ASEAN Community: An Overview. In S. Das, J. Menon, R. Severino, and O. Shresta, eds. The ASEAN Economic Community: A Work in Progress. Manila: ADB and Singapore: Institute of Southeast Asian Studies.

World Trade Organization (WTO). 2011. The WTO and Preferential Trade Agreements. World Trade Report 2011. Geneva. 


\section{Realizing an ASEAN Economic Community: Progress and Remaining Challenges}

Launched as a political bloc and security pact in the aftermath of the Viet Nam War, the Association of Southeast Asian Nations (ASEAN) has evolved to embrace an ambitious economic agenda. Its latest project is to establish the ASEAN Economic Community (AEC) by 31 December 2015. Fulfilling these commitments would promote predictability in ASEAN, as well as strengthen its credibility. But is ASEAN likely to meet this deadline? This paper finds that although ASEAN has come a long way towards realizing the AEC, the remaining challenges suggest that the deadline will be missed.

\section{About the Asian Development Bank}

ADB's vision is an Asia and Pacific region free of poverty. Its mission is to help its developing member countries reduce poverty and improve the quality of life of their people. Despite the region's many successes, it remains home to the majority of the world's poor. $A D B$ is committed to reducing poverty through inclusive economic growth, environmentally sustainable growth, and regional integration.

Based in Manila, ADB is owned by 67 members, including 48 from the region. Its main instruments for helping its developing member countries are policy dialogue, loans, equity investments, guarantees, grants, and technical assistance. 